\title{
PSYCHOPHYSIOLOGICAL SEQUELAE OF HOLOCAUST TRAUMA IN A JEWISH CHILD
}

\author{
Moshe Halevi Spero
}

This paper explores neurotic and religious components of conversion and psychophysiological sequelae of Holocaust trauma in a child of concentration camp inmates. The patient is a 26-year-old married woman of orthodox Jewish faith, whose presenting symptom was noncyclic uterine bleeding. The uniqueness of the symptom is emphasized within the defensive use it represents of the ritual menstrual code of the patient's orthodox Jewish way of life. Complexities in differentiating the symptom as either psychosomatic, hysterical, or both, as well as some of the sociocultural background which lends significance to the patient's symptoms, are discussed below.

This study is intended as a contribution to the literature on the treatment of religious patients. As this case study deals indirectly with the effects on the psychological health of their post-war child of parental pathology resulting from concentration camp experiences, it will be a contribution to the slowly growing body of literature examining this important topic. ${ }^{1-8}$

Recent psychiatric literature contains relatively few detailed case studies focusing on the unique neurotic or disordered uses of religious institutions within the defensive or symptomatic characteristics of the religious patient. ${ }^{9-19}$ This is possibly because of a philosophical unwillingness to view such clientele as presenting unique therapeutic challenges, or a general failure to appreciate the defensible clinical need to approach such patients with two conceptions: the patient qua patient and the patient qua religious individual. Part of this failure has to do with therapists' assumptions about the value of religion itself as a meaningful social institution. Yet, as I have noted elsewhere, there is no hard and fast rule that dictates that analytic patients be treated independently of, or in ignorance of, it or despite their religion. ${ }^{18}$ Rather, religious institutions that have been co-opted to serve defensive functions in the case of the neurotic patient need to be considered, and treated, within the overall context of the balance of healthy religiosity and unhealthy religiosity.

Moshe Halevi Spero, M.S.S.W., M.A., Department of Social Work and Social Science (Psychology), The University of Michigan. 


\section{RELIGIOUS BACKGROUND}

The nexus between person as patient and person as religious believer is but one clinical complexity relevant to the case at hand. Another clinical issue has to do with personality conceived of as the nexus between psyche and soma, an inextricable relationship graphically illustrated in the etiology and treatment of psychosomatic illness and, to a greater degree, in the hysterical neuroses.

The classic hysterical symptom of conversion reaction-somatic dysfunction with no physical cause - in addition to the broad constellation of hysterical characterological patterns, is a prime example of the power of psychic processes over physical equilibrium. Hysterical symptoms and those psychosomatic symptoms that have their bases in the dispositions of hysterical personality are conspicuous by their intricate symbolic associations and meanings for the patient and, often, by a curious patient apathy about these symptoms (so-called la belle indifférence). ${ }^{20}$ This apathy is more correctly a dissociation by the patient of the symptom from conscious awareness. In certain cases, it is difficult to draw clear diagnostic lines between the purely hysterical and the purely psychosomatic. Hysterical conversion symptoms tend to have symbolic meanings which relate to the general hysterical personality. On the other hand, true psychosomatic illness has not been considered to bear symbolic or dynamic significance, nor is it viewed as a defense against anxiety-both characteristic of true neurotic symptomatology. ${ }^{20}$ Rather, it is the failure of other defense mechanisms to protect the ego against anxiety that precipitates the onset of psychosomatic disorder. While debate continues among those who argue for specific relationships between physical symptom and dynamic significance $\mathrm{e}^{20-23}$ and those defending more-generalized stress-adaptation theories, ${ }^{24,25}$ still others have attempted to obviate the fuzziness between psychosomatic and hysterical pathology by rejecting entirely the clinical division between them. ${ }^{26,27}$

Holistic diagnosis, accordingly, takes into account the possibility that even "true" psychosomatic symptoms can become compliant with the unconscious behavior-organizing needs of the ego (following Shapiro) ${ }^{28}$ (The opposite also occurs; e.g., anorexia nervosa, which, though functional in origin, eventually leads to actual physiological alterations and morbidity.) When dealing with the hysteric or hysterical personality type-given their general disposition toward repression and somatic compliance when anxiety threatens-even ostensibly psychosomatic symptoms need be considered with an eye toward possible symbolic significance. This is in keeping with the broadly based view that psychophysiological manifestations are part of a total mind/body process involving a multiplicity of organizational, developmental, and social factors. ${ }^{29}$ 
Also relevant here is the relationship between cyclic and irregular hormonal levels and psychosexual development and balance. Women are more particularly subject to cyclic hormonal upheavals with conspicuous psychological concomitants, though the possibility of cyclic mood swings in men is currently being investigated. Benedek's and Rubenstein' $\mathrm{s}^{22}$ classic correlation between ovarian/hormonal functions and the psychodynamic processes and themes seen in female analytic patients (perhaps an atypical population) has been incorporated into the modern literature on feminine psychology. ${ }^{30}$ It also appears that the evolution of feminine identity, which includes socialization through established sociocultural and familial roles and norms, as well as psychophysiological adaptation to unfolding hormonal changes, has established preferences toward certain types of defense mechanisms or classes of defensive adaptation. ${ }^{30-32}$ This is not meant to imply that anatomy determines destiny. Rather, these considerations support the notion that when social or religious institutions emphasize an inseparable relationship between body integrity and personal status or self-worth-in our case, between the natural process of menstruation, the religious rituals attendant to it, and the role of Jewish womanhood - the tone is set for likely somatic targets which might be incorporated by a hysteric into her armamentarium of symbolic displacements. The sexual organs and their various libidinized functions (e.g., elimination, menstruation, procreation) readily become objects for distorted drive derivatives in conversion symptoms (e.g., vaginismus, pseudocyesis), though highly sexualized conflict may also be displaced to some symbolically relevant alternative locus-e.g., gagging when discussing sexual episodes or blindness when recalling a sexual scenario. Additional symbolic values derived from social input add complexity to the task of aiding the patient in unraveling symptom meanings and differentiating the real self from the selfin-bondage.

There is a final note concerning the present patient's religious world. A critical aspect of orthodox Jewish life is obediance to Halakhah, a body of religious and ethical practices and beliefs covering every nuance of daily behavior and interpersonal relationship. Halakhah is extremely sensitive to the relation between the menstrual cycle and psychological variables that affect it or are affected by it. Applebaum has carefully reviewed the relevant halakhic literature and highlights examples of its very early recognition of many of psychosomatic gynecology's more recent discoveries, such as the role of chronic stress, fear, and trauma in the development of amenorrhea and breakthrough bleeding and the relationship between the premenstrual physical syndrome and depression..$^{33}$

While the complexity of the Jewish menstrual laws can be outlined only briefly here; this religious code calls for abstinence from all forms of sexual intimacy for the period of time beginning with the onset of menses through 
seven days after the ritual determination of the cessation of menstruation. The woman must find no evidence of bleeding during this period, or the count of days must begin anew. If there are no complications, a woman then immerses herself in the ritual pool, thus suspending the period of abstinence. Should a woman at any time experience uterine bleeding (not traceable to any organic lesion), an abstinence period would have to be observed by the couple until some intervention appropriate in the eyes of Jewish law were implemented.

Insightful sociopsychological rationale have been offered for these laws. ${ }^{34,35}$ In general, these laws were early recognized by the rabbinic tradition as one of several imperatives whose partial function was the sublimation of instinctual expression. Such explanations themselves have been considered essential components of the philosophy of Jewish family life and are included in the educational curricula of every orthodox Jewish school. The point is that the present patient would certainly have been exposed to these teachings and laws by the time she was 12 years old.

\section{SYMPTOMATOLOGY}

Sara, an only child, was born and raised in a vibrant, middle-class orthodox Jewish community in the United States. Her parents, refugees from the Nazi extermination camps, were hard working, quiet, and respectable members of their Jewish community. Sara's childhood through early adulthood years were unmarked by extraordinary physical development. Two years after graduating from parochial high school with high marks, Sara graduated from a religious teachers' seminary and taught in local Jewish religious schools. Teachers' evaluations noted that Sara was "bright, yet quite talkative"; others more critical stated, "Sara is too caught up in appearances." One perceptive eleventh-grade instructor noted, "Though Sara is a conscientious, intelligent person, there is something about her demeanor with her superiors that just borders on the flirtatious." It is noteworthy that several of her teaching supervisors commented on the excellent rapport she rapidly developed and sustained with her students and fellow women teachers.

As is customary in such communities, a woman of about 18 years old is considered eligible to participate in arranged dating. Sara, though eligible in more ways than one, put off such offers until she was 21 and had completed her seminary studies, confiding to others that she considered men a "distraction" from her "obligations" to Jewish studies. When she finally began dating, she was not merely disinterested in, but, in her words, "abjectly disgusted with" each of 50 prospective suitors. At age 24, Sara met Leon, a 27-year-old graduate student in education and, concurrently, a student in an orthodox rabbinical seminary. Leon was the perfect suitor and attended to Sara's every whim. They had no physical contact, which, in orthodox Jewish circles, is forbidden among the unmarried. 
Sara's interest in Leon waxed and waned over the course of a year's relationship; she basked in his attentiveness one moment and-often the same day or hour-became enraged over what she considered major insensitivities ("He refused to walk to the curb-side of the street," "His hat was unstylishly tilted"). More than once she threatened to terminate their relationship, claiming not to understand why she was interested in Leon in the first place. Characteristically, Sara ignored or could not recall such outbursts when Leon would dare make mention of them, or she would wave them away with a thin laugh as not being representative of her "true" feelings. Undaunted, Leon twice proposed marriage to Sara. Each time she responded optimistically that she just needed time to "gather up the emotions," yet, after thinking for a full week following Leon's proposals, responded blandly that if he felt the union was made in heaven she would accept.

Leon backed off for a while, although they continued dating, and after two months he proposed for a third and final time. Sara accepted, but not before letting Leon know that "truly no man" was her perfect mate. Sare enjoyed the spotlight throughout the period of wedding preparations and during the wedding itself. During the two months prior to the wedding, Sara claimed not to have time to see Leon because of her hectic schedule and appointments. (Whether Leon had any intuitive appreciation of his bride's hysterical personality and narcissistic qualities by this point is moot; suffice it to say that his perceptions may very well have been involved in a type of collusion that frequently exists between seemingly mismatched partners, a collusion unconsciously designed to satisfy neurotic needs of both partners.)

More obvious symptomatology surfaced quite early in their marriage: from the wedding night, pronounced vaginismus made sexual intercourse impossible. This condition, in fact, persisted until the date of referral six months later. Sara was more aggravated by Leon's patient ministrations than with her vaginismus and their unconsumated marriage. Sara used various ploys to also avoid more general forms of intimacy, frequently voicing the opinion that "sex is not a vital part of marriage for people who know religious selfcontrol." Sara would explode with indignation about the "world's preoccupation with sex" at Leon's attempts at physical contact or at correcting the situation by seeking professional advice. She would usually terminate all discussion of their sexual relationship with something to the effect of, "Anyhow, I have something more important to attend to." Sara was unperturbed about their sexual relationship, and often asked Leon if he was as happy with their relationship as she was. Thus, the impression emerged that Sara's vaginismus did not fit into the pattern of a generally adjusted, loving, and sexually desirous spouse suffering from a localized pain reaction.

After three months, Leon issued a courageous ultimatum, and Sara agreed to an appointment with a gynecologist to whom she expressed her consternation with her husband's overreactions to a "minor problem" which would 
probably go away of its own accord in due time. The physician noted the pronounced vaginismus and told Sara that he wished to schedule another appointment to implement gradual muscle dilation exercises. At this suggestion, Sara became anxious and agitated and loudly accused the physican of seductive intentions. She stormed out of his office exclaiming that gynecologists have nothing better to do than "poke around the insides of their patients."

At this juncture, Sara's symptomatology altered. Sara was to have gone to the ritualarium the evening of the gynecological appointment. However, upon leaving the doctor's office, she experienced a sensation of breakthrough bleeding and later discovered that she had indeed spotted. In accordance with Jewish law, the abstinence period would have to be temporarily extended. Sara was unconcerned. After a week and a half of continuous spotting, and again only upon Leon's adamant insistance, Sara met with her internist. He could find no physical cause, but prescribed an oral contraceptive in an attempt to curtail the bleeding. Although the bleeding soon stopped, Sara continued to experience the sensation of strong uterine contraction which, according to Jewish law, imposes the menstruant status upon the woman. After another week of this third variation in symptoms, Leon informed Sara that their rabbi was considering some lenient ruling on her behalf which could terminate her menstruant status. Immediately, Sara experienced the familiar sensation of uterine cramping and shortly after, she discovered that she had begun spotting again. Sara's physician, wary of prescribing more medication and by now suspicious of psychogenic origins of the symptoms, recommend psychiatric counseling. This was the background of Sara's referral to me, reconstructed from initial history-taking, the physicians' reports, and subsequent interviews with Sara and Leon.

\section{TREATMENT}

I conducted psychoanalytic psychotherapy with Sara, meeting four times a week for almost five months and twice weekly for the last two months. Prior diagnostic testing suggested that Sara was a hysterical neurotic with some borderline trends, with available and generally well-functioning defenses against anxiety, the conversion symptom notwithstanding. There was a marked tendency to rely on denial where repression failed. Though her excellent WAIS did not itself rule out the borderline possibility, her projective protocols did not contain the confabulatory responses and bizarre, inhuman ideation typical of borderline personalities. Her responses to several Thematic Appreception (TAT) pictures and the content of her early memories dealt significantly with themes of early loss and depression, physical injury, and oedipal issues. Yet, she had considerable ego structure, fairly well- 
differentiated self and object images, and a capacity for empathy. The following is a synopsis of the major therapeutic developments to the point of termination of therapy.

Sara began therapy with predictable characterological defenses; notable was an effluvium of pseudoaffectiveness marking her lack of real affectionateness and an inability to appropriately gauge feelings. Undercurrents of impulsivity, depression, self-destructiveness, and aggression were characteristic of her early interaction with the therapist and highlighted the intensity of her apparent object hunger and early experiences of maternal deprivation. As Sara began to focus more clearly on childhood issues, she began to challenge earlier denials of her family's destructive emotional atmosphere and her repression of traumatic childhood fantasies and nightmares. These were partly stimulated by her parents' frequent and deatiled descriptions of concentration camp experiences and by their use of these descriptions to enforce discipline.

Toward the fifth week of therapy, Sara began producing dreams involving themes of destruction, death, and the spillage of blood. In relating one particular dream about a rapidly revolving, pulsating bed, she moved her head around as if experiencing vertigo. When she finished relating the dream, she tilted her head back, slumped into her chair, and exlaimed that she felt "dead." At other times, Sara would become mute, press her legs together, or gag, when approaching memories or impulses that were less well-defended.

During an intense transference episode (sixth week), Sara reacted to the therapist's reserve and to her parent's coldness and withdrawnness. Sara began to be aware of intense anger against her father, yet she still guarded against full expression of it by reminding the therapist that "a good Jewish father figure must remain a little aloof." Soon, Sara began dissolving the aspects of an oedipal triangle wherein her mother passed Sara to her father as the token female sexual object.

Pubertal crises were abreacted during the ninth week. Sara was now able to less defensively confront her intense hatred of her father for rejecting her femininity at puberty. Sara related that her mother would emphasize that menstrual blood was the "blood of death," synonomous with infertility, disease, human destruction, and Hitler's vengance against the Jews. "In those horrible months," Sara's mother once told her daughter of her camp internment, "I never saw 'the Guest." (Jewish tradition employs "the Guest" as a euphemism for the regularly recurring menstrual cycle. Applebaum notes that the cessation of menstruation was a common reaction to concentration camp internment. ${ }^{33}$ ) Sara's mother often told her that "Beauty like yours cannot exist for long ... there are always Hitlers who would love to spill Jewish blood." Already strong oedipal conflicts readily encouraged young Sara's displacement of castration fears and bodily preoccupations onto hatred of her father, 
men in general, and finally her own husband. Paternal and maternal introjects that plagued Sara and compromised a more appropriate identity formation gained additional tenacity through unworked grief for her mother, who died three years earlier; Sara's guilt manifested itself in self-destructive fantasies and in a functional uterine anomalie which also caused a temporary inability to have children.

A critical turning point in therapy came with Sara's recollection, initially through screen memories and finally in almost original form, of her traumatic witnessing of her mother miscarrying a three-month-old fetus in the bathroom, screaming hysterically, "This is my blood, your blood, Jewish blood, spilled by Hitler!" Sara, age 11, gagged and "almost fainted," and ran to her father for help. Sara recalled that he, rather disgustedly, refused to come, and instead called the police. Numerous aspects of this complicated reconstruction, its traumatic and symbolic import on Sara's general character and her specific symptom, could now be worked through over the course of the fourteenth and fifteenth weeks of therapy. The disgust with which she perceived matters sexual was strongly related to the extreme death anxiety created by her mother and fostered by Sara's own need for punishment in the face of violently angry feelings toward her parents. In this setting, the trauma of the mother's miscarriage came almost as a confirmation of both women's pathological fantasies and expectations. During the next two weeks of therapy, Sara dreamed and spoke of wanting the symptom to reappear, but it did not.

Additional time was then spent reworking her feelings toward her parents, although further work was necessary with regard to her mother. Sara began to relate to this material and felt that she and Leon needed to "rework" their relationship so "that it would be a marriage, and not a concentration camp for him and me." Leon wished to obtain some sexual counseling together with Sara, at which point I referred the couple to the community family service agency.

\section{DISCUSSION}

Erikson lent an important understanding to what we know about defensive mechanisms in general when he noted that there is something of a "human unconscious determination not to face childhood anxiety again." ${ }^{\prime 36, p .403}$ It is in the texture of interactions in childhood that so much of future personality development is determined. The emotional atmosphere which permeated the environment of child Sara was one of depression, death, solitude; an atmosphere in which normal psychosexual tasks were encumbered by a depressed, hysterical, emotionally absent mother and a passively seductive yet 
prohibitive father, openly condemnatory of his daughter's sexuality at puberty. In the classic paradigm of the development of hysteria, Sara served her father as the emotional substitute for her mother-who was crippled by her own pathological asexuality and need for self-punishment-and was reinforced temporarily by her father for adopting this nurturant role. Aspects of Sara's parents' own pathology, generally referred to as "survivor's syndrome" (as distinguished by some authors from "traumatic war neurosis"), were discussed in therapy but are beyond the scope of this analysis. Relevant insights into this continuing problem, including growing recognition of the psychological effects of parental Holocaust experiences upon their postwar children, are available elsewhere. . $^{1-8,36 a, 36 b}$

With her mother's gradual emotional withdrawal, which began in subtle ways in infancy and early childhood, Sara's need for object relationship was satisfied by her father, yet his binding her into this relationship further retarded her own subsequent differentiation from him during the oedipal period. Indeed, her sexual disillusionment during this period was brought on abruptly by paternal rejection of and disgust for the very characteristic Sara had begun to accept as ego-syntonic.

The frequent unconscious perception in such patients of holding the family together was experienced by Sara in terms of being "sometimes good for one (parent) and sometimes good for the other. ${ }^{\prime 37}$ Yet, it was perhaps due to this premature sense of importance and ability to control-which later manifested itself in her pathological interpersonal relationships--that Sara was able to survive her childhood experiences with a relatively strong ego.

With regard to the oedipal aspect of the father-daughter relationship, there was no one single trauma, but rather the continuing "seductive" style of relationship within the context of the oedipal struggle, that was the basis for Sara's eroticization of nonsexual relationships as a means of control and manipulation. Sara avoided the experience of being overwhelmed by reversing the power relationship which existed between her and her father-by becoming herself the seductive, exploitative, withholding one--and exercising this power over men in general, with her husband, and, in the early stages of therapy, with the therapist.

The particular focus of therapy, however, was not exclusively Sara's general hysterical characteristics, but also her conversion symptom, although the one cannot be completely understood outside the context of the other. Her tendency toward acting out through additional conversion symptoms which occurred during therapy (gagging, swooning, inability to talk) has to do partly with learning family rules regarding affect: the proscription against talking about feelings, the denial of feelings surrounding issues such as menstruation, past parental history, the miscarriage. Distorted affective impulses were reex- 
pressed in terms of bodily preoccupations. Sara, for example, recalled how she used to pick at sores and cause them to bleed, knowing that the sight of blood would extract at least a modicum of attention-though not appropriate sympathy or feeling-from her mother. Here, then, is the disposition favoring somaticizing instead of expressing feeling in more appropriate manners. Her specific symptom of uterine bleeding could be considered psychosomatic inasmuch as this aberration involved actual tissue changes and, as part of a bodily response to emotional needs, may have had a complex hormonal basis. It is nonetheless a functional condition replete with psychological significance intimately related to the specific symbols that are recurrent in the patient's conflict.

It is the particular somatic symptom that highlights some of the uniqueness of Sara's case. To be sure, it was Freud who contributed the notion that any specific symptom adopts numerous layers of symbolic significance that are "lent to it, imbedded in it, as it were." ${ }^{38}$ Yet, it was left largely to the therapist and patient to discover the exact nature of the relationships between bodily symptom and psychosocial significance. Cameron makes another relevant point in observing that it is not the bodily tissues as such-the real hand, eye, genital, etc.- - that is most significant in the study of the psychosomatic symptom, but rather the social hand or other organ, with its social connotations, that clarifies the meaning of the specific somatic compliance. ${ }^{39}$ Yet a third clinical contribution to understanding Sara's symptom is found in Erikson's comment, "No individualty [exists] which does not reflect latent concerns of the group. ${ }^{\prime \prime 36, p .36}$ His meaning is obvious, and its implication for this case is that the deepest significance of Sara's particular symptom choice may lie in since-closed pages of psychohistorical drama involving the gradual process of the renunciation and sublimation of instinctual demands and fears in the face of the demands of religion. (Indeed, it was Erikson who analyzed the case of "Sammy" with an eye to the relevance of the historic context of the development of Jewish identity to the immediate life experiences of this small boy.) $)^{36, p .30-31}$

On the immediate, dynamic level, Sara's bleeding is oedipally determined and is related to conflict themes of castrating and being castrated or bleeding to death; power, control, and manipulation; and self-punishing identification with her mother's pathological preoccupations. Sara's parents interfered with the role of menarche as an "organizer" in feminine development and with her ability to accept menstruation without ambivalent feelings. ${ }^{39 a}$ Blood had been construed to signify death, eliciting negative maternal introjects as well as horrible fantasies of concentration camp existence and torture. Though triggered later in life than the actual traumata which lent such significance to the bleeding, the reality of her own possible childbearing stirred up repressed memories of her confused feelings upon witnessing her mother's miscarriage 
and a resultant fear of retribution by her recently deceased mother-the mother's dark powers now fantasized as even greater because of Sara's guilt over her death.

Another significance of Sara's symptom involves institutions and attitudes of orthodox Judaism vis-á-vis the menstrual taboo. Though conceived of as not simply a capricious method for rendering women "unfit" when convenient, nor merely a replication of taboo domains of tribal life, this code contends with active countercurrents both in personal attitudes toward limiting pleasure and in the powerful force of the instincts modified by these laws. Yet, vigilant adherence to this code despite the above and throughout numerous periods of religious persecution has concretized, as part of the social role of the orthodox Jewish woman, the conception of the nonmenstruant state as one of peak creativity, and the menstruant state as one of relative noncreativity. That is, the identity of the observant Jewish woman is inextricably related to the sense of trust granted to her through this code in monitoring and safeguarding the sanctity of the natural processes of sexuality and creativity. I believe that it is within this context that the particular attrocities perpetrated upon many Jewish women in the Nazi concentration camps took on their most tragic meanings. It is within this context, too, that Sara's mother experienced such trauma during her internment when her sexuality was affronted and not defended; an affront experienced not just "sexually" but also as an attack on her psychological identity as a Jewish woman. Even following her release from the physical environment of the camp, living was now more a matter of dying each day, and sexuality became a function disjointed from its normal significances. It was this caricature of sexuality, rather than the healthier version experienced by others not involved in this historic catastrophe, into which Sara was educated. It was the death symbolism lent by Sara's mother to her child's natural bodily processes which disposed Sara to her own unique mis-use of these religious laws, given all the other conflicts surrounding her own psychological and self-development.

Sara's religiosity bears the earmarks of neurotic religion. ${ }^{18,40}$ in her fastidious observation of the menstrual code, Sara practiced the letter of the law, to be sure, yet around her own defensive uses of it. Her religious personality was characterized by rigidity, fixation, and dissociation; she had convinced herself that Judaism somehow approved of her sexual style. In fact, whereas Judaism grants sexuality a certain circumscribed status, Sara allowed sexuality no ontological status, and her symptom expressed this negativism. The clinical problem is the following: the patient has "religious beliefs" about menstruation, sexuality, and marriage, yet the therapist knows them to be neurotic. If Judaism demands the limitation and control of sexual expression, the patient's disordered personality demanded limitation and control in pathological extreme. In this light, her beliefs cannot be said to function as 
religion; they are primarily defenses. Yet to what extent is the patient a "religious individual" and to what extent a "neurotic individual?" This is precisely the issue many therapists avoid or are uncomfortable with, which has perhaps led to the relative disinterest in such types of cases.

The answer would seem to lie in how much the ego is capable of responding to the constructive, growth-provoking aspects of religion. Yet, consider Sara. Does one attack the pathological religiosity in toto in the hopes that a new and vital commitment will follow the liberation from neurosis? I stated once, "For on the one hand, we may know that the patient is doing ritual $X$ for rigid, anxiety-wrought reasons, yet the ritual per se (in its basic form) becomes thereby no less of a religious requirement." ${ }^{18}$ That is, while Sara's defensive use of the menstrual code is not appropriate, nonetheless, as a basically reality-oriented individual, she is still religiously obligated to this institution. Before her psychotherapy, these laws were victimized, as it were, by the patient's neurotic abuses of them, much the same as her speech, cognitive, and affective apparati were co-opted by the neurotic organizing processes within. Following this analogy, a therapist is as ill-advised not to accept the patient as a religious individual as one would be to refuse to accept the patient as a thinking, speaking, or emoting individual. Rather, one treats the way the patient perceives himself or herself to be a religious individual, aiding the patient to experience the given religion in a healthier light. What a patient then does with religion is not a psychotherapeutic goal, although it is a therapeutic concern how a patient functions as an individual with his or her given modes of religious expression.

Religion has been characterized as a problem-solving effort. ${ }^{40}$ To the degree that any individual uses religion to problem-solve issues such as psychic conflict in ways which, in turn, are limiting to the true functions and scope of religion, such religiosity becomes of psychotherapeutic interest. Sara's religious commitment to the Jewish menstrual code was not geared for personal or religious growth, but rather represented a repetition of unresolved childhood conflicts. The symbolic significances of these conflicts were particularly compatible with aspects of Sara's general religious requirements and were subsequently elaborated through continuous trauma along developmental stages involving her biological functions and psychosexual maturation. Sara thus incorporated a powerful defensive structure allowing her to continuously reexperience the psychological and historical conflicts of her childhood, while appearing to function as a scrupulous and appropiately observant lewish woman.

\section{REFERENCES}

1. Charney, I. Teaching the violence of the Holocaust. Religious Education, 2: 15-24, 1968. 
2. Kanter, 1. Social psychiatry and the Holocaust. /. Psychol. Judaism, 1(1): 55-66, 1976.

3. Klein, $\mathrm{H}$. Holocaust survivors in kibbutzim: readaptation and reintegration. Isr. Ann. of Psychiatry, 10(1): 78-91, 1972.

4. Krystal, H. Massive Psychic Trauma. New York: International Universities Press, 1968.

5. Kohn-Dor-Shav, N. On the long-range effects on concentration camp internment on Nazi victims: 25 years later. J. Consult. and Clin. Psychol., 46(1): 1-11, 1978.

6. Anthony, E. J., \& Koupernik, C. (Eds.) The Child and his Family: the Impact of Disease and Death. Vol. 2. New York: Wiley, 1973.

7. Phillips, R. E. Impact of Nazi Holocaust on children of survivors. Am. /. of Psychother, 32(3): 370-377, 1978.

8. Neiderland, W. Clinical, social, and rehabilitation problems in concentration camp survivors. J. Jewish Communal Service, 42(2): 186-191, 1965.

9. Apolito, A. Psychoanalysis and religion. Am. J. of Psychoanal., 30(2): 115-123, 1970.

10. Beit-Hallahmi, B. Encountering orthodox religion in psychotherapy. Psychotherapy: Theory, Research, and Practice, 12(4): 357-359, 1975.

11. Bronner, A. Psychotherapy with religious patients. Am. J. of Psychother., 18(3): 475-487, 1964.

12. Cohen, R., and Smith, F. Socially reinforced obsessing: etiology of a disorder in a Christian-Scientist. J. Consult. and Clin. Psychol., 44(1): 142-144, 1976.

13. Ekstein, R. A clinical note on the therapeutic use of a quasi-religious experience.). Am. Psychoanal. Assoc., 4: 304-313, 1956.

14. Lorand, P. Psychoanalytic therapy with religious devotees. Int. I. Psychoanal., 43: $50-56,1962$.

15. Novey, $S$. Utilization of a social institution as a defense technique in the neuroses. Int. J. of Psychoanal., 38(1): 82-91, 1957.

16. Rubins, J. Neurotic attitudes toward religion. Am. J. of Psychoanal., 5: 71-81, 1955.

17. Slawson, P. Treatment of a clergyman: anxiety neurosis in a celibate. Am. /. Psychother., 27(1): 52-60, 1973.

18. Spero, M. H. Clinical aspects of religion as neurosis. Am. J. Psychoanal, 36(4): 361-365, 1977.

19. Whitlock, F., and Hynes, I. V. Religious stigmatization: an historical and psychophysiological study. Psychol. Med., 8(2): 185-202, 1978.

20. Alexander, F. Psychosomatic Medicine: its Principles and Applications. New York: Norton, 1950.

21. Dunbar, F. Emotions and Bodily Changes: a Survey of the Literature on Psychosomatic Interrelationships 1910-1953. New York: Columbia University Press, 1954.

22. Benedek, T., and Rubenstein, B. The Sexual Cycle in Women: the Relationship Between Ovarian Function and Psychodynamic Processes. Washington, D. C.: National Research Council, 1942.

23. Grace, W., and Graham, D. Relationship of specific attitudes and emotions to certain bodily diseases. In L. Gottschalk et al. (Eds.), Psychosomatic Classics. New York: Karger, 1972.

24. Selye, $H$. The Stresses of Life. New York: McGraw-Hill, 1956.

25. Malmo, R. Physiological concomitants of emotion. In A. Freeman and H. Kaplan (Eds.) Comprehensive Textbook of Psychiatry. Baltimore: Williams \& Wilkins, 1972. 
26. Ziegler, H., Imboden, J., and Meyer, E. Contemporary conversion reactions: a clinical study. Am. J. of Psychiatry, 116: 901-910, 1960.

27. Ziegler, $\mathrm{H}_{\text {., }}$ and Imboden, J. Contemporary conversion reactions: a conceptual model. Arch. Gen. Psychiatry, 6: 279-289, 1962.

28. Shapiro, D. Neurotic Styles, New York: Basic Books, 1965.

29. Grinker, R., and Robbins, F. Psychosomatic Casebook. New York: Blakiston, 1954.

30. Bardwick, J. Psychology of Women: a Study of Bio-cultural Conflicts, New York: Harper \& Row, 1971.

31. Thompson, C. Cultural pressures in the psychology of women. Psychiatry, 5: $331-339,1942$.

32. Wolowitz, H. Hysterical character and feminine identity. In J. Bardwick (Ed.), Readings in the Psychology of Women. New York: Harper \& Row, 1972.

33. Applebaum, D. Psychological aspects of the menstrual laws. /. Psychol. and Judaism, 2(1), 55-70, 1977.

34. Lamm, N. A Hedge of Roses, New York: Feldheim, 1960.

35. Tendler, M. D. A Marriage Manual for the Jewish Family. Jerusalem: Center for Preservation of Jewish Family Purity, 1967.

36. Erikson, E. Childhood and Society. New York: Norton, 1963.

36a. Furman, E. The impact of the Nazi concentration camp on the children of survivors. Paper Presented at the American Psychoanalytic Association, December 19, 1971.

36b. Lipkowitz, $M$. The child of two survivors: A report of an unsuccessful therapy. israeli Annals of Psychiatry and Related Disciplines, 1973, 11(2): 141-155.

37. Slipp, S. Interpersonal factors in hysteria. J. Am. Acad. Psychoanal., 5(3): 359$376,1977$.

38. Freud, S. Dora: an Analysis of a Case of Hysteria. New York: Collier, 1905/1963.

39. Cameron, N. Personality Development and Psychopathology. Boston: Houghton-Mifflin, 1963.

39a. Kestenberg, J. Menarche. In S. Lorand and H. Schneer (Eds.) Adolescents. New York: Hoeber, 1961.

40. Pruyser, P. The seamy side of current religious beliefs. Bull. Menninger Clin., 41(4): 329-349, 1977.

Reprint requests to 37-02 Shannon Road, Cleveland Heights, $\mathrm{OH} 44118$. 